7. Навчальна інфраструктура закладу вищої освіти [2].

Таким чином, до автомеханіка за фахом «Обслуговування та ремонт автомобілів і двигунів» пред'являються не тільки вимоги до знань 3 основ теорії і практики професійних навичок, від випускників так само потрібна наявність організаційно-управлінських і аналітичних навичок, уміння ефективно працювати в колективі, приймати рішення і нести за них відповідальність.

\title{
Література:
}

1. Кашина Г. С. Аналіз формування фізико-технічної освіти в процесі навчання студентів автотранспортних коледжів. Наукові записки НДУ імені М. Гоголя. Психолого-педагогічні науки. - 2016. № 7. - С. 16- 20 .

2. Слабко В. М., Макієвський О. І. Особливості формування фахових компетентностей майбутніх фахівців транспортної галузі у процесі вивчення спеціальних дисциплін. Науковий часопис нац. пед. універ. імені М.П. Драгоманова. Серія 5. Педагогічні науки: реалії та перспективи. - Випуск 78. - Київ : Видавничий дім «Гельветика», 2020. - C. 202-207.

3. Bludova T., Halakhova T., Gromozdova S., Kashina G., FrolovaT. The system of modern university missions realization in the measurement of three key components. International Journal of Engineering and Advanced Technology (IJEAT), Volume-9, Issue-2, December 2019, Pp. 2588-2595.

DOI https://doi.org/10.30525/978-9934-26-114-5-53

\section{ОСОБЛИВОСТІ НАВЧАННЯ АУДІЮВАННЯ ЯК ЗАСОБУ РОЗВИТКУ ІНШОМОВНОЇ КОМУНІКАТИВНОЇ КОМПЕТЕНЦЇ̈ НА ЗАНЯТТЯХ УКРАЇНСЬКОЇ МОВИ ЯК IHOЗЕМHОÏ}

\author{
Мацюк Г. Р. \\ викладачка кафедри української та іноземних мов
}

Тернопільський національний технічний університет імені Івана Пулюя м. Тернопіль, Украӥна

Слухання та розуміння усної інформації в процесі спілкування $\epsilon$ надзвичайно важливим, оскільки вміння слухати значною мірою забезпечує ефективність комунікативної діяльності людей. За 
допомогою аудіювання відбувається передача знань, обмін інформацією; ним пронизаний весь процес навчання. Аудіювання $є$ основою для оволодіння іншими видами мовленнєвої діяльності: читанням, говорінням, письмом.

Особливе значення в процесі адаптації іноземних студентів в україномовному середовищі відводиться формуванню вміння розуміти почуте та спілкуватися в різних повсякденних ситуаціях. Тому навчанню аудіювання як виду мовленнєвої діяльності на заняттях української мови як іноземної приділяється значна увага, оскільки аудіювання є одним із головних способів вивчення іноземної мови, що розвиває навички та вміння усного мовлення.

Проблему навчання аудіювання досліджують науковці: Ю. Баранова, О. Березовська, О. Бігич, С. Гапонова, I. Круківська, I. Лисовець, В. Мазниченко, О. Метьолкіна, А. Неділько, О. Семотюк, Н. Харченко, I. Шимків та ін. Аналіз їхніх праць дає підстави зробити висновок, що аудіювання розглядається як один із засобів розвитку іншомовної комунікативної компетенції, розуміння сприйнятого на слух усного мовлення, здатність ідентифікувати та розуміти усні висловлювання, є самостійним видом мовленнєвої діяльності.

Як зазначає О. Семотюк [1, с. 98] досягнення базового рівня аудіювання в сучасних вищих навчальних закладах повинно передбачати формування в іноземних студентів елементарної комунікативної компетенції в цьому виді мовної діяльності. Тому навчання аудіювання на заняттях допоможе іноземним студентам сформувати вміння комунікативної компетенції.

Послідовність формування вмінь розуміти мовлення на слух, зняття труднощів змістового сприйняття тексту здійснюється шляхом виконання вправ: сприйняття мовлення на слух 3 певним дидактичним завданням.

У методичній літературі [2-4] пропонується система вправ для навчання аудіювання, яка включає дві підсистеми: вправи для формування мовленнєвих навичок аудіювання та вправи для розвитку вмінь аудіювання.

Перша підсистема містить три групи вправ: вправи для формування фонетичних навичок аудіювання, вправи для формування лексичних навичок аудіювання та вправи для формування граматичних навичок аудіювання, які поділяються на некомунікативні (вправи на сприйняття, розрізнення звуків, лексичних одиниць чи граматичної структури) та умовно-комунікативні рецептивні (вправи на аудіювання повідомлень, запитань, розпоряджень та ін.). Завдання вправ першої підсистеми - сформувати в іноземних студентів слухові навички, які 208 
виробляють розвиток фонетичного й інтонаційного слуху, а також лексичні й граматичні навички аудіювання.

Розглянемо деякі вправи 3 першої підсистеми, які ми пропонуємо іноземним студентам на заняттях $з$ української мови як іноземної на початковому етапі вивчення мови.

Вправи на розвиток фонетичних навичок аудіювання: наприклад, підняти руку, якщо ви чуєте голосні звуки $(n, \pi, o, c, \epsilon, y, 4, u \ldots)$, Звук «с» $(M, n, o, c, \kappa, 3, c, y, c, i, u, c \ldots)$, відкритий склад (-oм-, -нi-, -na-, -ук-, -cu-, -iфb-...), наголос падає на другий склад (númu, чита́mu, працюва́mu, бízamu, сиді́mu ...) та ін. Завдання таких вправ - навчити студентів розрізняти звуки, склади, слова.

Вправи на розвиток інтонаційного слуху: наприклад, визначити питальні речення (Ми читаємо книжки. Ми читаємо книжки? Діти люблять морозиво? Діти люблять морозиво. Вони часто купують молоко. Ви любите танцювати? Сьогодні буде падати дощ. Учора було сонячно? та ін.). Завдання - навчити іноземців розрізняти інтонацію питальних і розповідних речень.

Вправи на розвиток лексичних навичок аудіювання. Це вправи на семантизацію слів, речень. Наприклад, підняти руку, коли картинка i почуте слово співпадають (теми: «Частини тіла», «Моя квартира», «Овочі та фрукти», «Тварини» та ін.), визначити «правда» чи «неправда» (Узимку иввітуть квіти. Навесні йде дощ. Улітку падає град. Восени садять дерева. Навесні жовтіє та опадає листя та ін.) відгадати загадки, за характеристикою людини назвати іiі професію, сказати, де вживаються почуті фрази та ін. Такі вправи навчають іноземних студентів розуміти актуальне значення почутої лексичної одиниці.

Використання вправ на розвиток граматичних навичок аудіювання дозволяє формувати в студентів навичок розпізнавання лексичнограматичного матеріалу. Наприклад, записати в зошит тільки іменники жіночого роду (брат, вікно, життя, мати, подруга, стіл, зошит, земля $m a$ ін.), прослухати дієслова та записати дієслова доконаного виду (прочитати, пити, лізти, спати, випити, намалювати, з їсти, купувати, зрозуміти, малювати та ін.), дієслова в минулому часі (зробив, читаю, написала, їм, помолилися, написав, з їм, зробимо, спить та ін.), підняти руку, коли чуєте речення в теперішньому часі (Кожного дня мій друг встає рано. Чистить зуби, умивається $i$ йде снідати. Але вчора він прокинувся пізно. Був дуже злий, бо запізнився на автобус. Щосуботи він грає футбол з друзями. Проте завтра вони не будуть грати. Він також любить читати книжки. Зараз сидить на дивані та читає детектив.) та інші вправи. 
Практикування на заняттях української мови як іноземної вправ на розвиток фонетичних, лексичних, граматичних навичок аудіювання сприяють розвитку лексичних, граматичних і фонетичних навичок іноземних студентів та доведення їх до автоматизмів.

Друга підсистема вправ охоплює вправи, що готують студентів до аудіювання текстів та вправи у власне аудіюванні текстів. Як зазначається в методичній літературі до цієї підсистеми входять умовно-комунікативні (аудіювання повідомлень, запитань, розпоряджень на понадфразовому рівні) та комунікативні рецептивні вправи (вправи на аудіювання текстів 3 метою одержання інформації). Завдання цих вправ - розвинути в студентів уміння аудіювання.

Ми використовуємо в роботі зі студентами вправи на передбачення змісту тексту, визначення логічної послідовності подій, розуміння тексту, розуміння основної думки та ін. Наприклад: продовжити розповідь, запропонувати свій варіант розвитку подій, передати почуту розповідь 4-6 реченнями, розмістити малюнки (запропоновані речення) відповідно до подій у тексті, чи прозвучало в тексті запропоноване речення, визначити невідповідності зображеного на малюнку і почутого в тексті, який текст точніше описує запропонований малюнок та ін. Такі завдання допомагають іноземним студентам оволодіти вміннями передбачати зміст, виділяти головне, порівнювати почуте та побачене, встановлювати логічну послідовність подій, причиннонаслідкові зв'язки.

Робота 3 розвитку навичок та вмінь аудіювання нами проводиться на кожному практичному занятті вивчення української мови як іноземної, оскільки аудіювання $є$ не лише метою навчання, а й засобом оволодіння мовним матеріалом. Тематика аудіоматеріалів відповідає тематиці конкретного практичного заняття та практикується разом 3 навчанням інших видів мовленнєвої діяльності: говорінням, читанням та письмом.

Таким чином, забезпечення успішного процесу комунікації та розвитку вміння іноземних студентів спілкуватися українською мовою реалізується завдяки правильній організації навчання аудіювання на заняттях, що і $є$ однією з основних умов успішного оволодіння іноземною мовою.

\section{Література:}

1. Семотюк О. Особливості застосування аудіювання у процесі вивчення української мови як іноземної. Обрії. 2013. № 1. С. 98-100.

2. Зимняя И. А. Психология обучения иностранным языкам. Москва : Просвещение, 1991. 206 с. 
3. Лазаренко К. А. Основи методики навчання іноземним мовам. Київ : Вища школа, 1997. 230 с.

4. Метьолкіна О. Б. Методичні рекомендації щодо організації індивідуального навчання аудіювання. Київ : Київський державний лінгвістичний університет, 1994. 65 с.

DOI https://doi.org/10.30525/978-9934-26-114-5-54

\title{
РОЗВИТОК ТВОРЧОГО ПОТЕНЦАЛУ МАЙБУТНІХ ЛІКАРІВ У ПРОФЕСІЙНІЙ ОСВІТІ
}

\author{
Мінухіна Д. В. \\ PhD, асистент кафедри внутрішньої медицини № 2 i клінічної \\ імунології та алергології імені академіка Л. Т. Малої \\ Харківський національний медичний університет \\ Мінухін Д. В. \\ кандидат медичних наук, доцент кафедри хірургї̈ № 1 \\ Харківський начіональний медичний університет \\ Свтушенко Д. О. \\ доктор медичних наук, професор кафедри хірургї̈ № 1 \\ Харківський національний медичний університет \\ м. Харків, Україна
}

Метою сучасної медичної освіти $\epsilon$ всебічний розвиток людини як особистості й найвищої цінності суспільства, іiї талантів, розумових і фізичних здібностей. У зв'язку з великою швидкістю змін у медицини зростає потреба суспільства у всебічній творчій активності сучасної людини, спроможної розв'язувати безліч різноманітних, в першу чергу медичних професійних завдань. Професія лікаря - одна 3 таких професій, що вимагає перманентного самовдосконалення та використання всіх розумових можливостей людини $[1,2]$.

Професійна підготовка майбутніх лікарів має бути орієнтована на формування не лише лікарської компетентності, а й готовності випускників до участі в забезпеченні гармонійного розвитку фізичних і духовних сил, високої працездатності й довголітнього активного життя громадян [1,3].

Актуальність теми обумовлюється також необхідністю визначення й експериментальної перевірки сукупності педагогічних умов, що забезпечать ефективне формування творчого потенціалу майбутніх 